\title{
Fundamental Rights of States: Constitutional Law in Disguise?
}

\author{
Helmut Philipp Aust*
}

\begin{abstract}
This contribution analyses the development of the doctrine of fundamental rights of states in German international legal doctrine. It shows how the doctrine, despite its natural law origins, was able to adapt and flourish in a more positivist environment in the late nineteenth and early twentieth century. It was highly malleable with respect to the uses to which it was put. Accordingly, it was relied on in order to support National Socialist conceptions of international law as well as to connect with a return to natural law after the Second World War. With a turn to more pragmatist approaches in German scholarship since the middle of the twentieth century, the doctrine seemed to have faded away. However, this contribution argues that it has witnessed a somewhat unexpected comeback. Driven by some functional and constructive analogies with parts of the constitutionalisation literature, it is possible to see traces of the doctrine re-emerging. In this respect, it may even be said to resemble parts of the recent case law of the German Federal Constitutional Court, which has put a strong emphasis on sovereignty and self-determination as limits of international and European integration.
\end{abstract}

\section{Keywords}

Fundamental Rights of States, German Scholarship on International Law, Natural Law, Positivism, Constitutionalisation

The doctrine of the fundamental rights of states (FRS) is shrouded in mystery. For quite a long time, it was a building block of international law scholarship, to the extent that it has been argued that more or less all of 'classical international law', from its Vattelian origins until the Second World War, was based on this doctrine. ${ }^{1}$ Hans Kelsen described the doctrine in this way:

* Senior Research Fellow and Privatdozent, Faculty of Law, Humboldt University, Berlin (Germany); Visiting Professor at the University of Konstanz. I would like to acknowledge the inspiring environment at the Institute for International Law and the Humanities, Melbourne Law School, where parts of this article were written. I am grateful to the friends and colleagues present at the authors' seminar at the University of Alabama Law School in April 2015, as well as to Bardo Fassbender, Thomas Kleinlein, Felix Lange, John Morss and Anne Orford for their comments, criticism and feedback. Any errors or misconceptions are mine. 
According to a view prevailing in the eighteenth and nineteenth centuries and maintained even today by some writers, every state has-in its capacity as a member of the family of nations-some fundamental rights. These rights are not stipulated by general customary international law or by international agreements, as the other rights and duties of the states are, but originate in the nature of the state or of the international community. The norms constituting these fundamental rights are supposed to be the ultimate basis and source of positive international law and, consequently, to have a greater obligatory force than the rules of positive international law created by custom and treaties. ${ }^{2}$

Different grounds of this doctrine have been identified. While its roots lie in natural law thinking, the doctrine has also flourished in more positivist times. Over the course of the centuries, the list of the respective candidates for the status of the FRS has remained fairly stable, with the rights to independence, self-preservation, equality, respect-of honour and dignity of the state-as well as intercourse between states being the usual contenders. ${ }^{3}$ It is not the purpose of this contribution to assess this or competing catalogues of the individual candidates for being FRS. ${ }^{4}$ Rather, this paper will look at the doctrine of the FRS from a historical-doctrinal perspective, assessing how the doctrine has been subject to adaptation and contestation over the years. It is, thus, not so much the content of the FRS, but rather the notion itself to which the following pages are dedicated. In doing so, this paper focuses on the contribution of German international legal scholarship, understood in a wide sense to comprise authors who were trained in a German-speaking legal environment but may have continued their academic careers abroad, especially after the rise of the National Socialists to power, when a large part of the elite of Germany's international legal scholarly community was forced to emigrate.

In any case, it can be said that German international lawyers made significant contributions to the debate on the FRS. Why is this? A first guess would probably be to turn to Hegel and his glorification of the state as the ultimate representative of progress and morality. ${ }^{5}$ However, this guess is somewhat misguided. The understanding of international law that Hegel exposed in his philosophy of law is difficult to reconcile with the doctrine of the FRS, at least as it developed in the first place. As is commonly asserted, the FRS doctrine is an offspring of the analogy of states with individuals, both having the same capacity to hold rights and obligations. ${ }^{6}$ Hegel was highly critical of

1 Emmanuelle Jouannet, The Liberal-Welfarist Law of Nations: A History of International Law (CUP 2012) 124.

2 Hans Kelsen, Principles of International Law (Rinehart 1952) 148-49.

3 See Ricardo J Alfaro, 'The Rights and Duties of States' (1959) 97 Recueil des Cours 91, 95ff; José M Ruda, 'States, Fundamental Rights and Duties' in Rudolf Bernhardt (ed), Encyclopedia of Public International Law, Instalment 10 (North Holland Publishing 1987) 468.

4 For such analysis, see other contributions to this special issue in (2015) 4 CJICL.

5 For a nuanced view on Hegel, see Armin von Bogdandy and Sergio Dellavalle, 'Georg Wilhelm Friedrich Hegel (1770-1831)' in Bardo Fassbender and Anne Peters (eds), The Oxford Handbook of the History of International Law (OUP 2012) 1127.

6 Gilbert Gidel, 'Droits et Devoirs des Nations: La Théorie Classique des Droits Fondamentaux des États' (1925) 10 Recueil des Cours 539, 550; Charles de Visscher, Theory and Reality in Public International Law (Percy E Corbett tr, Princeton UP 1957) 18; Hans Ulrich Scupin, 'Grundrechte und Grundpflichten 
this conception of the state, arguing that: 'States are not private persons but completely independent totalities in themselves, and so the relation between them differs from a moral relation and a relation involving private rights.7

At the same time, certain connections between Hegelian thinking about 'the state' and the category of FRS cannot be overlooked. Hegel's philosophy of rights discussed questions of international law under the rubric of 'external state law', thereby contributing much to later ideas of 'foreign relations law' as opposed to international law proper. ${ }^{8}$ This engendered an emphasis on independence and sovereignty, all the while acknowledging that 'a state is as little an actual individual without relations to other states (...) as an individual is an actual person without a relationship to other persons. ${ }^{9}$ However, despite this recognition of interdependence, '[t]he people as a state is spirit in its substantial rationality and immediate actuality and is therefore the absolute power on earth'. ${ }^{10}$ This emphasis on state power might have been a reason why the doctrine of the FRS has fallen out of favour over the last decades. Although Hegel cannot be attributed with a decisive influence on the doctrine of the FRS, his views are at times associated with the glorification of the state which was found to be pre-eminent in German international law scholarship from the late nineteenth to the middle of the twentieth century. ${ }^{11}$

Whatever one sees in the doctrine, it has an immediate bearing on the very structure of international law. ${ }^{12}$ It raises a number of doctrinal and theoretical questions and is a prism through which the evolution of international law scholarship can be seen. The following remarks should not be seen as an attempt at a genealogy. Rather, this article enquires into the construction of a doctrinal figure in international law by means of an exposition of key contributions to the academic debate, sometimes linked to developments in the practice of international law or the

der Staaten' in Hans J Schlochauer (ed), Wörterbuch des Völkerrechts, vol 1 (2nd edn, De Gruyter 1962) 726; Wilhelm G Grewe, The Epochs of International Law (Michael Byers tr, De Gruyter 2000) 415; Miloš Vec, 'Grundrechte der Staaten: Die Tradierung des Natur- und Völkerrechts der Aufklärung' (2011) 18 Rechtsgeschichte 66, 72; Jean d'Aspremont, 'The Doctrine of Fundamental Rights of States and Anthropomorphic Thinking in International Law' (2015) 4 CJICL 501. See generally on the problematic tradition of conceiving of states as individuals the recent contribution by John R Morss, International Law as the Law of Collectives: Toward a Law of People (Ashgate 2013) 73ff.

7 Georg Wilhelm Friedrich Hegel, Outlines of the Philosophy of Right (TM Knox tr, rev edn, OUP 2008) s 330.

8 cf Jochen von Bernstorff, The Public International Law Theory of Hans Kelsen: Believing in Universal Law (CUP 2010) 17-18.

$9 \quad$ Hegel (n 7) s 331.

10 ibid (emphasis in original).

11 For a connection between Hegel and the doctrine of the FRS, see, eg, Alfred Verdross, 'Die Wertgrundlagen des Völkerrechts' in H Klecatsky and others (eds), Die Wiener rechtstheoretische Schule, vol 2 (first published in (1953-54) 4 Archiv des Völkerrechts 129 (Europa-Verl 1968)) 2194-95. On the impact of Hegel on German international law scholarship, see also the nuanced treatment in Martti Koskenniemi, The Gentle Civilizer of Nations: The Rise and Fall of International Law 1870-1960 (CUP 2002) 179ff. For a more positive assessment of Hegel, see Morss (n 6) 26.

12 Erich Kaufmann, Das Wesen des Völkerrechts und die Clausula Rebus Sic Stantibus: Eine rechtsphilosophische Studie zum Rechts-, Staats- und Verfassungsbegriff (Mohr Siebeck 1911) 69. 
broader political environment in which the discourse took place. It hopes to escape the otherwise inevitable criticism for methodological problems associated with the writing of international legal histories. The ever-present danger of anachronism and a decontextualised presentation of legal principles as concepts falling from the sky should be acknowledged and, as much as possible, avoided. ${ }^{13}$ Accordingly, this article will not sketch the development of the doctrine of the FRS as a story of progress in which international law has finally learnt to overcome the doctrine. What this article sets out to do, instead, is to shed light on a somewhat unlikely re-emergence of the doctrine, if not in name, then in substance. I will argue that parts of the recent scholarship on the constitutionalisation of international law have paved the way for this development and that this has gone hand in hand with the case law of the German Federal Constitutional Court on the limits of European and international integration. The doctrine has surfaced, vanished and resurfaced over time and has served different purposes. In order to set the scene for this argument, it will first be necessary to provide a few snapshots on the development of the doctrine in German international legal scholarship. These snapshots are highly selective in nature. They will concentrate on contributions which this author is convinced have had a lasting impact on the development of the doctrine of the FRS. In the following, I will first discuss how the doctrine was developed, flourished and was subsequently abandoned in the time between the early nineteenth and mid-twentieth centuries. In this period, international legal scholarship gradually moved away from natural law thinking towards a more positivist style of reasoning. Accordingly, section two will discuss how the doctrine of the FRS oscillated between these two poles in this period. Following on from that, section three will canvass how the doctrine of the FRS was resurrected, yet abandoned again in the time of National Socialism. Interestingly, the same movement-from reaffirmation to abandonment-can again be detected in the post-Second World War era. As section four demonstrates, a return to natural law thinking in the founding years of the Federal Republic later yielded to a turn to pragmatism which had difficulties in connecting with the doctrine of the FRS. Somewhat unwittingly, we can now-in the post-Cold war era-again detect figures of argumentation which do not in name resurrect the doctrine of the FRS, but resemble certain traits of it. Section five will be devoted to this unlikely comeback. From this tour d'horizon it emerges that over the last two centuries, there was constant movement in German international legal scholarship between affirmation and denial of the doctrine of the FRS. It appears, as will be argued in the concluding section, that the doctrine of the FRS is usually invoked in times of upheaval and change.

13 On these dangers and ways to overcome them, see Anne Orford, 'On International Legal Method' (2013) 1 London Rev Intl Law 166; Martti Koskenniemi, 'Vitoria and Us: Thoughts on Critical Histories of International Law' (2014) 22 Rechtsgeschichte 119. 


\section{From natural law to positivism}

From the late eighteenth until the early twentieth century, the doctrine of the FRS has found different foundations in German scholarship. First identified with natural law thinking, the doctrine managed to survive the rise of positivism, despite growing criticisms about its circularity and heavy blows inflicted by a Kelsenian form of deconstruction.

\subsection{Natural law origins: The state as individual}

At the very roots of the doctrine of the FRS was the analogy between states and natural persons. ${ }^{14}$ As Bardo Fassbender has remarked, 'In the age of enlightenment, the idea of an equality of States was based on an analogy with the "natural" status of men.15 This can, to some extent, be seen as a parallel development to the transfer of sovereignty from prince to nation..$^{16}$ If, traditionally, the prince had been seen to embody the polity and had possessed certain rights inherent to this position, it was only natural to transfer these rights to states as newly emerging units of political order. ${ }^{17}$ Today, this analogy may appear to be misguided. It would be too easy, however, to dismiss it altogether. As Emmanuelle Jouannet has pointed out, this move brought about a new form of thinking of states as equals, whereas previously different polities were generally thought to be unequal. ${ }^{18}$ According to Hans Ulrich Scupin, the development of the doctrine was most importantly shaped by Vattel who relied on the works of Christian Wolff. Vattel, however, would have been more 'consequentalist' than Wolff, especially in terms of keeping apart the domains of law and ethics. ${ }^{19}$ Wolff's construction of the FRS was anything but straightforward. It, too, was premised on the understanding that nations would be equivalent to individuals in a state of nature. ${ }^{20}$ In this state of nature, there would be nothing except natural law. ${ }^{21}$ In Wolff's civita maxima, this state of nature was supplemented by the positivist law of nations, comprising voluntary, stipulative and customary law of nations. ${ }^{22}$ Wolff then distinguished the duties of nations towards themselves and the duties of nations towards each other. The latter category can be understood as an early emanation of the doctrine of the FRS, as Wolff wrote that '[e]very nation owes to every other nation that which it

14 See, in greater detail on these origins, the contribution of d'Aspremont (n 6).

15 Bardo Fassbender, 'Article 2(1)' in Bruno Simma and others (eds), The Charter of the United Nations: A Commentary, vol I (3rd edn, OUP 2012) 133. See also Scupin (n 6) 726.

16 Morss (n 6) 73.

17 Fassbender (n 15) 141.

18 Jouannet (n 1 ) 36.

19 Scupin (n 6) 726.

20 Christian Wolff, Jus gentium method scientifica pertractatum, vol II (Clarendon Press 1934) s 2.

21 ibid s 3.

22 See also Stephen C Neff, Justice Among Nations: A History of International Law (Harvard UP 2014) 245. 
owes to itself. ${ }^{23}$ Chief among the duties of nations towards themselves was the idea of self-preservation: 'Every nation is bound to preserve itself.' ${ }^{24}$

\subsection{From natural to inherent rights: The rise of positivism}

Natural law thinking fell out of favour with the rise of positivism in international law. One would suppose that this should have rung the death knell for the doctrine of the FRS. After all, how should this doctrine be accommodated in a legal structure, which put a premium on state consent? How could it be possible to argue at the same time that international law knew only a certain number of formal sources, yet hold that some rules would be superior to others and did not depend on the volition of states-in the late nineteenth century arguably the only subjects of international law ${ }^{25}$

Despite its natural law pedigree, the doctrine of the FRS was able to mutate and adapt itself to more positivist leanings. In this new guise, the doctrine was reframed as 'deriving, rather, from logical, historical, sociological or even positive bases', which, as Jouannet rightly notes, 'made their fundamental character problematic'. She asks, 'In what respect did such rights remain absolute and fundamental?' ${ }^{26}$ Illustrative of the construction of the doctrine of the FRS in positivist writing is the work of Franz von Liszt, author of the leading German textbook on international law at the beginning of the twentieth century. ${ }^{27}$

Liszt argued for the necessity of fundamental rights of states which would not be natural law illusions, but legal norms, the existence of which would derive quasiautomatically from the concept of Völkerrechtsgemeinschaft (international law community), without which international law would be inconceivable. ${ }^{28}$ It was almost akin to notions of Begriffsjurisprudenz-or the infamous heaven of concepts ${ }^{29}$ - when Liszt argued that it followed from the very concept of international law as a community of states with equal rights that every member of this community would have a right to equality vis-à-vis all other members of the community-not even to mention the

23 Wolff (n 20) s 156.

24 ibid s 31.

25 cf Scupin (n 6) 727.

26 Jouannet (n 1) 125.

27 Hans Kelsen, Das Problem der Souveränität und die Theorie des Völkerrechts: Beitrag zu einer Reinen Rechtslehre (Mohr Siebeck 1920) 215. See further Florian Herrmann, Das Standardwerk: Franz von Liszt und das Völkerrecht (Nomos 2001).

28 Franz von Liszt, Das Völkerrecht: Systematisch dargestellt (11th edn, Springer 1921) 59. A similar form of reasoning can be found in Lassa Oppenheim, International Law: A Treatise, vol I (Longmans Green 1905) s 112 ('it must be taken into consideration that under the wrong heading of fundamental rights a good many correct statements have been made. (...) They are rights and duties which do not rise from international treaties between a multitude of States, but which States customarily hold as International Persons, and which they grant and receive reciprocally as members of the Family of Nations'). The formulation remained virtually unchanged in the later editions prepared by Hersch Lauterpacht, International Law: A Treatise by Lassa Oppenheim, vol I (6th edn, Longmans Green 1947) s 112.

29 See further Karl Larenz, Methodenlehre der Rechtswissenschaft (Springer 1969) 17ff. 
circularity of reasoning involved here. ${ }^{30}$ To Liszt, the community of nations under international law was based on the idea of the parallel existence of different states with well defined zones of authority, with mutually recognised spheres of power. From this basic consideration, a number of legal principles would flow automatically, without a need to ground them in treaty law. They would form the basic stock of unwritten international law and would be its oldest, most important and even holiest part. ${ }^{31}$

Liszt was too much the archetypical positivist to dwell on long philosophical musings about the FRS after this passage. Instead, he delved directly into specific questions of statehood, territory and sovereignty, which he discussed without further references to the category of fundamental rights. This category re-emerges, however, in the next section of his book, which is devoted to the 'völkerrechtlicher Verkehr', the intercourse between states. In this respect, he accorded the right to intercourse between states prime importance. In the transboundary flow of people, goods and ideas, the idea of belonging to the community of states would materialise. Exclusion of a state from this intercourse would be equivalent to the process of individuals being outlawed in the Middle Ages. ${ }^{32}$ Accordingly, Liszt again resorted to the analogy with individuals here. In more concrete terms, he points to the jus comercii as an expression of this principle. ${ }^{33}$

\subsection{Coping with circularity: Jellinek, Kaufmann and self-preservation}

With Liszt, it appears as if the heyday of the uncritical affirmation of the doctrine of the FRS was probably reached. The belief in the FRS as a self-evident category of international law was lost and authors began to wonder more regularly how those rights could be constructed. Most writers appeared to be sceptical about their existence in the first place. ${ }^{34}$ Yet, there were variations with respect to the resoluteness with which authors refuted the doctrine of the FRS. Georg Jellinek can be counted among the most radical critics. In his 1882 monograph on the system of subjective rights in public law, he included a chapter on the FRS. Whereas in all other parts of law, natural law would have been put to rest, it would 'continue to indulge in its well-known orgies in international law, only to be vehemently interrupted from time to time by the deniers of international law, then to begin anew afterwards.' ${ }^{35}$ In any case, he found the doctrine to be circular in nature, only positing that a state would have a right to be a state and that this right would need to be respected by other states. ${ }^{36}$

30 von Liszt (n 28) 58.

31 ibid 59.

32 ibid 100. This idea somewhat foreshadows later works by Wolfgang Friedmann, The Changing Structure of International Law (Columbia UP 1964) 88ff in which Friedmann wrote about the sanction of exclusion from participation.

33 von Liszt (n 28) 100.

34 Scupin (n 6) 726-27.

35 Georg Jellinek, System der subjektiven öffentlichen Rechte (2nd edn, Mohr Siebeck 1905) 311.

36 ibid 314. 
To a certain extent, this line of reasoning was also followed by Erich Kaufmann in his notorious monograph on the clausula rebus sic stantibus - that is, the possibility of modifying treaty commitments in the case of a fundamental change of circumstances. ${ }^{37}$ Quite similar to Jellinek, he remarked that the right to equality would mean nothing more than the concept of legal subjectivity as such. ${ }^{38}$ Although his monograph was only concerned with the clausula, it dealt a wider blow to the idea of the FRS, but with a twist, as we shall see. Kaufmann engaged in a vast survey of the literature, where the clausula is connected to the doctrine of FRS. He drew attention to the diverging strands of argument to be found in these sources. He remarked that some authors would discuss the clausula without a reference to the idea of the FRS, despite apparently noticing that there would be a significant overlap of their ideas with this doctrine. Others would equivocate with respect to the precise fundamental right in which the clausula would be anchored. Yet others would speak of a fundamental right, yet base it on the volition of the states concerned, thereby implying that it could also be derogated from. And still others would do away with the category of FRS and would import their contents into other legal institutes such as the state of necessity or the defence of exceptio non adimpleti contractus. ${ }^{39}$ Eventually, Kaufmann seemed to show a considerable degree of scepticism as to whether a category of FRS can exist in the first place without dismantling international law of its quality of law as such. He affirmed that whether the existence of FRS can be affirmed would be a principal problem, which would be closely connected with the very structure of international law as a legal system of 'individuals' (Individualrechtsordnung). He noted that there would be no right to self-preservation and independence for individuals; and thus, how could there be one for states without doing away with international law as law? ${ }^{40}$ With the vanishing away of natural law, any idea of fundamental rights preceding the state would vanish too, he argued. Fundamental rights would always need to be based on positive legislation; they would not be rights inherent to the individual. ${ }^{41}$

So far, Kaufmann's analysis reads almost Kelsenian. However, Kaufmann takes a somewhat surprising U-turn, decoupling international law from its individualistic thinking. For international law, the idea of a fundamental norm, being placed above treaty relations, would be essential. ${ }^{42}$ What did Kaufmann have in mind? Did he aspire to bring all the FRS back in through the rear door? Not at all. He criticised most of them

37 On Kaufmann and this book, see Koskenniemi (n 13) 179ff. For an in-depth biographical analysis, see Frank Degenhardt, Zwischen Machtstaat und Völkerbund: Erich Kaufmann (1880-1972) (Nomos 2008) as well as Reut Yael Paz, A Gateway between a Distant God and a Cruel World: The Contribution of Jewish German-Speaking Scholars to International Law (Martinus Nijhoff 2013) 170ff. In contemporary international law, the clausula is now set forth in art 62 of the Vienna Convention on the Law of Treaties (adopted 23 May 1969, entered into force on 27 January 1980) 1155 UNTS 331 (VCLT).

38 Kaufmann (n 12) 195.

39 ibid 68-69. In contemporary international law, this ground would be covered by VCLT, art 60.

40 Kaufmann (n 12) 69.

41 ibid 194. Similarly on this point, see Viktor Bruns, 'Völkerrecht als Rechtsordnung' (1929) 1 Zeitschrift für ausländisches öffentliches Recht und Völkerrecht 1, 14 .

42 Kaufmann (n 12) 194-95. 
in a trenchant manner, discarding the right to independence as it would be a negation of international law. ${ }^{43}$ The right to equality would be a mere tautology and nonsensical. It would mean nothing more than legal subjectivity. ${ }^{44}$ The right to respect-or dignitycould hardly be more than a requirement of courtoisie. ${ }^{45}$ The right to intercourse would be no right. Instead, intercourse would be a social necessity in order to bring about international law. ${ }^{46}$ Yet the right to self-preservation, Kaufmann admonished, was indispensable. ${ }^{47}$ Kaufmann conceded that much of the criticism levelled against this right was correct. He reduced it to a core meaning-albeit fairly wide-ranging, one might add-that it would amount only to restoring independence in situations of changed circumstances, thus bringing it wholly in line with the subject matter of his book, the clausula. ${ }^{48}$ Self-preservation would be a truly fundamental right: it would entitle states to enter into international agreements necessary for their survival, but it would also entitle states to commit extra-contractual acts and terminate agreements. It would be the objective norm against which all state conduct could be measured: self-preservation could not be wrongful. ${ }^{49}$ Kaufmann saw the danger that this could be read as a negation of all law. He pointed to the limits in exercising this right, in particular necessity as a limiting factor. ${ }^{50}$ In addition, writing in 1911, he saw the high levels of armament among European powers as a guarantee against an abuse of this right. ${ }^{51}$ In coining a sentence that made him famous, he furthermore pointed out that in the international law of coordination, every state would only be entitled to those acts it could actually carry out. ${ }^{52}$

All in all, self-preservation was conceptualised by Kaufmann as something akin to jus cogens. It could not be altered by agreements. ${ }^{53}$ However, this kind of non-derogability was not considered in terms of substantive values. Kaufmann rather saw an inherent limit to the will of states at work: agreements would only be entered into under the condition that the fundamental circumstances under which they were concluded would not change in a way that would be incompatible with the right of self-preservation. ${ }^{54}$

\subsection{Deconstructing the doctrine}

While Kaufmann walked a fine line between doing away with the doctrine of the FRS and re-affirming parts of it-ie the right to self-preservation-other authors were more

43 ibid 195.

44 ibid.

45 ibid.

46 ibid 196.

47 ibid.

48 ibid.

49 ibid 199-200.

50 ibid 200.

51 ibid 201.

52 ibid ('Und endlich ist zu bedenken, daß im Koordinationsrecht jeder nur das darf, was er kann').

53 ibid 204.

54 ibid. 
consequentialist in their critique. Viktor Bruns, director of the Kaiser Wilhelm Institute in Berlin, maintained that, while there might be FRS, they would be based on positive law sources. To this extent, however, they would lose their succinct meaning. Writing about the FRS would mean nothing more than sketching the contours of all the existing rights and obligations of states. ${ }^{55}$

Although Bruns was in no respect inspired by Kelsen's Reine Rechtslehre, ${ }^{56}$ his analysis here reads almost Kelsenian in style. Indeed, Kelsen himself had little sympathy for any attempt to salvage the doctrine of the FRS which was, in his view, tainted by its natural law origins. ${ }^{57} \mathrm{He}$ found it impossible to deduce from 'nature' any rights. ${ }^{58}$ His rejection of the category of the FRS was inextricably linked to his methodological cornerstone of firmly distinguishing between the realm of the 'is' and the 'ought. ${ }^{59}$ Either natural rights would be stipulated by the positive legal order-then the category would be redundant and meaningless - or they would not have been embraced by positive law and a reference to natural rights would then be a call on the legislator to stipulate these rights. ${ }^{60} \mathrm{He}$ was also not any more welcoming of the idea that the FRS would be inherent to notions of statehood. This idea would only amount to natural law in disguise and could be refuted with the same arguments as above. ${ }^{61}$ Also understanding the fundamental rights as integral parts of the legal personality of states would be meaningless. The state would only be an international personality because of it being a subject of duties and rights. In essence, the FRS would ultimately collapse into the specific rights and obligations states have under international law. This would also explain why sovereignty would be nothing more than the sum of all these specific rights and duties. Sovereignty, in other words, was just a symbol for the system. ${ }^{62}$ Kelsen saw another problem with the doctrine of the FRS in its personification of the state. The state would be nothing more than individuals in their capacity as organs of the state. ${ }^{63}$ If the state came to be identified as a superperson' (Übermensch) or a super-human organism, this would be nothing else than a hypostatisation of this personification. ${ }^{64}$

55 Bruns (n 41) 14.

56 This seminal work, republished in multiple languages several times, was first published as Hans Kelsen, Reine Rechtslehre: Einleitung in die rechtswissenschaftliche Problematik (1934 F Deuticke).

57 Kelsen, Das Problem der Souveränität und die Theorie des Völkerrechts (n 27) 213-22. See also his later criticism of the International Law Commission's Draft Declaration on Rights and Duties of States: Hans Kelsen, 'The Draft Declaration on Rights and Duties of States' (1950) 44 AJIL 259 (this instrument is, however, more doctrinal in character). On this instrument, see Daniel H Joyner and Marco Roscini, 'Is There Any Room for the Doctrine of Fundamental Rights of States in Today's International Law?' (2015) 4 CJICL 467.

58 Kelsen, Principles of International Law (n 2) 149.

59 ibid 150. See also Hans Kelsen, General Theory of Norms (Michael Hartney tr, OUP 1991) 58ff.

60 Kelsen, Das Problem der Souveränität und die Theorie des Völkerrechts (n 27) 150.

61 ibid 151.

62 Hans Kelsen, Allgemeine Staatslehre (Springer 1925) 102ff.

63 Hans Kelsen, 'Souveränität' in Hans J Schlochauer (ed), Wörterbuch des Völkerrechts, vol 3 (2nd edn, De Gruyter 1962) 279.

64 ibid. This view was also shared by one of the most important students of Kelsen, Josef Kunz. Kunz drew a direct line from the-in his view-false personification of the state to the doctrine of fundamental rights. Under ancient Greek ideals, the state would have had no aims and purposes of itself, only the protection 


\section{In the name of equality? National Socialism and the fundamental rights of states}

It is difficult to assess what role the doctrine of the FRS had to play in National Socialist thinking on international law. To begin with, it is not easy to define the latter. There is no coherent Third Reich philosophy on international law and the uses to which international law was put during the reign of the National Socialists from 1933 to 1945 differed greatly ${ }^{65}$ It is probably fair to make two observations: first of all, international law was held in certain esteem if and to the extent that the new leaders considered it to be useful to the National Socialist regime. ${ }^{66}$ Under this guise, the doctrine of the FRS came back into fashion as part of the fight against the allegedly oppressive Treaty of Versailles - an endeavour, however, which had already united large parts of German academia in the Weimar era. ${ }^{67}$ Self-determination and equality of states were relied on in order to justify a gradual breaking away from the post-First World War order. ${ }^{68}$ Equality was deemed to be the fundamental building block of this critique. As Carl Bilfingerlater to be director of the Kaiser Wilhelm Institute after the death of Viktor Brunswrote in an early contribution to this question:

Who denies an independent state the status of equality, denies or negates this states' political independence in the sense of international law. (...) A consequence of equality between states is also an equality of rights, both as a principle and as a concrete demand. The more recent state practice demands under this heading of the equality of states that a state which is deemed to be independent and therefore legally equal with other states-and is being held responsible in this regard-has to be able and entitled to defend its quality with arms. ${ }^{69}$

Bilfinger made it clear that the basis for this fundamental right of states was to be sought neither in natural law thinking nor in its liberal-minded evolution into positivist international law. Rather, he deployed an analysis in tune with more general straits of National Socialist legal theory, somehow blending the German historical school, regarding law as a result of organic evolution ${ }^{70}$ with references to the new

of its citizens. Following on from the Renaissance, the state would have turned into a 'Makroanthropos', a Leviathan, with its own goals to be served by the citizens: Joseph Kunz, 'Völkerrecht, allgemein' in Hans J Schlochauer (ed), Wörterbuch des Völkerrechts, vol 3 (2nd edn, De Gruyter 1962) 615.

65 Detlev F Vagts, 'International Law in the Third Reich' (1990) 84 AJIL 661, 686; Michael Stolleis, A History of Public Law in Germany 1914-1945 (Thomas Dunlap tr, OUP 2004) 410.

66 Vagts (n 65) 663-64. On the skilful instrumentalisation of the right of self-determination by Hitler, see also Jörg Fisch, Das Selbstbestimmungsrecht der Völker: Die Domestizierung einer Illusion (Beck 2010) 182ff.

67 See John H Herz, 'The National Socialist Doctrine of International Law and the Problems of International Organization’ (1939) 54 Pol Science Q 536, 541; Vagts (n 65) 687-88; Stolleis (n 65) 60ff.

68 See, for instance, Gustav Adolf Walz, 'Das Verhältnis von Völkerrecht und staatlichem Recht nach nationalsozialistischer Rechtsauffassung' (1934) 18 Zeitschrift für Völkerrecht 145, 149; Paul Schoen, 'Erzwungene Friedensverträge' (1937) 21 Zeitschrift für Völkerrecht 277.

69 Carl Bilfinger, 'Zum Problem der Staatengleichheit im Völkerrecht' (1934) 4 Zeitschrift für ausländisches öffentliches Recht und Völkerrecht 481, 481 (translation by author).

70 On the historical school, see, for instance, Benjamin Lahusen, Alles Recht geht vom Volksgeist aus: Friedrich Carl von Savigny und die moderne Rechtswissenschaft (Nicolai 2013) 70-73. 
rulers' emphasis on the state as a representation of the people, understood in a racial (völkisch) sense. ${ }^{71}$ Carl Schmitt identified the equality of states with the doctrine of the FRS. In an exposition of the relationship between National Socialism and international law from 1934, he wrote that without fundamental rights no human community could exist. He was careful to note that these would not need to be fundamental rights akin to the ones known from nineteenth-century liberalism. He was adamant that fundamental rights could also exist in non-individualistic societies. To Schmitt, the doctrine of the FRS was alive as long as there was peace in the relations among European powers, a theme which is well known from his other works on the history of international law. ${ }^{72}$ Only in the decades leading up to the 1930s, the FRS had been buried under the 'rubble of positivism' and international pacts. It would be necessary to return to these older categories, especially for those states which had managed to reflect on their proper bases of internal order. National Socialist Germany would belong to these states. The primordial fundamental right would be the right to one's own existence, including the rights to self-determination, self-defence as well as the means of self-defence, again alluding to the limitations of armament, which Germany had to endure as a consequence of the Versailles peace settlement. ${ }^{73}$

This leads to a second observation in this context. What makes it difficult to portray the Third Reich era as a period in which the doctrine of the FRS fully flourished again was a gradual turn away from the state as the primary actor in international law. ${ }^{74}$ Although the alternatives put forward varied, thinkers close to the party, the government and the even more radical SS militia put forward the people (Volk) or the Reich as ultimately more relevant concepts, which would arguably be more akin to Germanic legal traditions. ${ }^{75}$ Also the so-called Großraumtheorie, propagated by Carl Schmitt in a 1939 lecture, can be seen in this connection. ${ }^{76}$ However, Schmitt himself insisted that states remained the key actors in international law ${ }^{77}$ despite his repeated musings about the decline of the state. ${ }^{78}$ This theory of legal spaces immune to outside intervention by foreign powers was difficult to reconcile with a doctrine of FRS, presupposing any measure of equality

71 Bilfinger (n 69) 482-84. On the implied inequalities of National Socialist writings on the equality of states, see also Herz (n 67) 544. On the importance of historical thinking for National Socialist law, see Bardo Fassbender, 'Stories of War and Peace: On Writing the History of International Law in the "Third Reich" and After' (2002) 13 EJIL 479, 496.

72 Carl Schmitt, Der Nomos der Erde im Ius Publicum Europaeum (Duncker and Humblot 1950).

73 Carl Schmitt, Frieden oder Pazifismus? Arbeiten zum Völkerrecht und zur internationalen Politik 1924-1978 (Günter Maschke ed, Duncker and Humblot 2005) 392-93.

74 At the same time, it should not be overlooked that the doctrine of fundamental rights kept constantly reappearing in contemporary writings, with authors often trying to accommodate it within National Socialist ideology: see, eg, Heinrich Korte, 'Lebensrecht und völkerrechtliche Ordnung' (1941) 25 Zeitschrift für Völkerrecht 131.

75 See, for instance, Walz (n 68) 147. On this development, see Vagts (n 65) 687; Stolleis (n 65) 411.

76 Carl Schmitt, Völkerrechtliche Großraumordnung mit Interventionsverbot für raumfremde Mächte. Ein Beitrag zum Reichsbegriff im Völkerrecht (1939, republished Duncker and Humbolt 1991).

77 Schmitt, Frieden oder Pazifismus? (n 73) 723.

78 Carl Schmitt, Der Begriff des Politischen (3rd edn, Duncker and Humblot 1963) 10. 
among states. This equality no longer played a role in National Socialist thinking as soon as the German Reich had shaken off the chains of the Versailles 'Diktat.'

\section{Post-Second World War movements}

With the collapse of the Third Reich, German international legal scholarship tried in many ways to start anew. These attempts departed on different pathways. First, a return to natural law thinking brought the doctrine of the FRS back into fashion before a turn to pragmatism led to a decline of this category in German academic circles.

\subsection{Natural law renaissance}

After the Second World War, German international legal scholarship witnessed a brief renaissance of natural law thinking. In fact, this renaissance was not limited to international law, but was rather a broader trend among German jurists. ${ }^{80}$ Positivism was accused of having paved the way for Nazi rule. ${ }^{81} \mathrm{Be}$ that as it may, the return to natural law thinking also brought about a renewed attention to the doctrine of the FRS. As Hans Ulrich Scupin wrote, the outcome of the Second World War had led to a process of transformation in international law. Established conceptions of natural law resurfaced, not in the forms of old theories, but as a fertile ground for the composition of new models of order. Yet again, this 'new international law' was torn by a clash between sovereignty and the demands of the international community. ${ }^{82}$

Evidence of this tendency can be found, for instance, in the work of Ulrich Scheuner, himself not wholly untainted by affiliation with the Third Reich regime, but not to the extent that it would have barred him from having a stellar career in West Germany. ${ }^{83}$ In a 1939 lecture at the Hague Academy, Scheuner had been highly critical of the doctrine of the FRS. To him, the doctrine would have represented an unfortunate assimilation of states with individuals. Individualism in general would have had an unfavorable influence on international society. What is more, it would have been wrong to assume that the international community would have subjected states to more and more restrictions. Due to a growing divide among states, the international order would be much less coherent than in previous, natural law-dominated times. ${ }^{84}$ Scheuner thus

79 Vagts (n 65) 688.

80 On the context of this development, see Lena Foljanty, Recht oder Gesetz: Juristische Identität und Autorität in den Naturrechtsdebatten der Nachkriegszeit (Mohr Siebeck 2013).,

81 For an argument in this direction, see Ulrich Scheuner, 'Naturrechtliche Strömungen im heutigen Völkerrecht' (1950) 13 Zeitschrift für ausländisches öffentliches Recht und Völkerrecht 556, 577, 589.

82 Scupin (n 6) 727 (with an unspecific reference to Scheuner).

83 Vagts (n 65) 677-78.

84 Ulrich Scheuner, 'L'influence du Droit Interne sur la Formation du Droit International' (1939) 68 Recueil des Cours 95, 188-90. 
called for an abandonment of the FRS. All this had changed, apparently, ten years later, when he wrote about the 'natural law tendencies' in international law. He underlined that the 'systematic construction of international law' would still rest on the FRS, carried forward from natural law origins. ${ }^{85}$

To some extent, Alfred Verdross can also be counted among those who contributed to this natural law renaissance after the Second World War. Verdross was, of course, already a leading international lawyer in the interwar period and probably the most prominent disciple of Kelsen in international law. ${ }^{86}$ That said, in methodological terms as well as moral outlook he parted from Kelsen's strict positivist analysis and embraced natural law as a way to come to terms with the Grundnorm. ${ }^{87}$ In an article published in the 1953-54 volume of the Archiv des Völkerrechts, he wrote about the foundation of values in international law. Verdross was deeply sceptical about the future of international law. A unity of values which underlay international law was gone, he argued. This development was spurred by a number of factors, amongst which he counted the Bolshevik revolution, Nazi rule in Germany-although he wrote that it was too short to leave any lasting impact on international law-and, most importantly, the process of decolonisation. Then asking what defined modern-to him Europeaninternational law, he turned to the FRS. The first and foremost value in international law would be the freedom of the respective people and groups of people, finding an expression in internal and external self-government. The mutual recognition of sovereignty would therefore be nothing less than recognition of this fundamental value of freedom and self-government of peoples. ${ }^{88}$ Verdross then turned to Hegel and his idea that recognition as a state was a vital requirement, embodying respect by other states for the independence and self-government of the recognised state. To Verdross, this recognition would encapsulate all other fundamental rights of the state, ie respect for their territorial sovereignty and internal order as well as the fundamental right of equality of states, in particular with respect to the exemption of states from standing trial in the courts of other nations. ${ }^{89}$

\subsection{Pragmatism takes over}

Not all writers who were close to the natural law renaissance followed this path. Some were cautious to base the FRS doctrine solely on natural law sources. Gerhard Leibholz, for example, primarily a constitutional law scholar and an influential judge at the Federal Constitutional Court, remarked that the equality of states would be a necessary

85 Scheuner (n 81) 574.

86 See, generally, Verdross' contribution to international law in Bruno Simma, 'The Contribution of Alfred Verdross to the Theory of International Law' (1995) 6 EJIL 33.

87 See on this question von Bernstorff (n 8) 114-16.

88 Verdross (n 11) 2194-95.

89 ibid 2195. 
component of any system of international law organised by way of coordination. Equality would be presupposed and, thus, an inherent part of legal subjectivity. ${ }^{90}$

In that sense, the FRS continued to have an impact on the discourse in Germany. ${ }^{91}$ It was, however, mitigated by practical demands-and possibly a wish of reintegration into the international community. Hermann Mosler, for instance, noted a tension between the category of FRS and the ever-growing restriction of the freedom of individual states. ${ }^{92}$ The works of Mosler may, to a certain extent, be seen as representative of a broader trend in post-Second World War scholarship in West Germany. Having had the privilege of practical experience through his work for the Federal Government in the early, formative years of the Federal Republic and a later director of the Max Planck Institute in Heidelberg-the successor institute to the Kaiser Wilhelm Institute in Berlin ${ }^{93}$-Mosler's sober approach to international law was typical of German scholarship from the 1960s to the 1980s, which tried to achieve practical progress in the reintegration of Germany into Europe and the broader community of (civilised) states. ${ }^{94}$ Mosler's conception of the international legal order is nicely encapsulated in a 1976 article devoted to a re-examination of the questions examined by his predecessor Viktor Bruns in the late 1920s. The doctrine of the FRS is still there, but it hardly plays an independent role. While the state is characterised as the unit for self-preservation of a people, ${ }^{95}$ the category of fundamental rights is dissolved into the concept of legal personality. From this subjectivity, certain rights-most importantly the right to existence-would automatically flow. ${ }^{96}$ In this respect, Mosler relied on Verdross and his idea that the recognition of a state would automatically entail respect for its existence and independence. However, Mosler did not go all the way towards disposing of the category of fundamental rights altogether. In particular, he insisted that states have a right of personality vis-à-vis the international order; an idea he took up from Bruns. Noticing that Bruns' suggestion was not successful among other authors, Mosler deemed it to be of greater value than the old imagination of the FRS-without however clearly delineating between the two. ${ }^{97}$

More categorical in his rejection of the FRS doctrine was Wilhelm Wengler, in many ways an antipode to Mosler. Difficult to place into the pragmatist mainstream, his work

90 Gerhard Leibholz, 'Gleichheit der Staaten' in Hans J Schlochauer (ed), Wörterbuch des Völkerrechts, vol 1 (2nd edn, De Gruyter 1962) 694.

91 See, eg, Karl J Partsch, 'Lebensinteressen' in Hans J Schlochauer (ed), Wörterbuch des Völkerrechts, vol 2 (2nd edn, De Gruyter 1962) 410.

92 Hermann Mosler and Hans-Otto Bräutigam, 'Staatliche Zuständigkeit' in Hans J Schlochauer (ed), Wörterbuch des Völkerrechts, vol 3 (2nd edn, De Gruyter 1962) 317.

93 See Felix Lange, 'Carl Bilfingers Entnazifizierung und die Entscheidung für Heidelberg' (2014) 74 Zeitschrift für ausländisches öffentliches Recht und Völkerrecht 697.

94 cf Georg Nolte, 'Zur Zukunft der Völkerrechtswissenschaft in Deutschland' (2007) 67 Zeitschrift für ausländisches öffentliches Recht und Völkerrecht 657, 657-59.

95 Hermann Mosler, 'Völkerrecht als Rechtsordnung' (1976) 36 Zeitschrift für ausländisches öffentliches Recht und Völkerrecht 6, 16.

96 ibid 22.

97 ibid 38-39. 
was certainly not characterised by natural law overtones, but rather by a sociological sensibility to a changing international environment. ${ }^{98}$ Wengler pointedly inquired into the practical workings of such a doctrine and remarked dryly that a special category of fundamental rights would only be meaningful if there would be special consequences attached to the violation of such fundamental rights or if they would be more difficult to abdicate through law-making between states. Neither would be the case. At most, he wrote, a presumption could be identified that the fundamental rights should not be limited, arguing along the lines of the in dubio mitius maxim of interpretation. ${ }^{99}$

It is important to acknowledge the changing normative environment in which these debates took place. Two developments stand out here, both eating away at the core of the doctrine of the FRS. For one, the emergence of international human rights law changed the vocabulary of international lawyers. Whereas the concept of fundamental rights was for a long time only known in international law as being associated with states as rightsholders, this has now changed. ${ }^{100}$ To a certain extent, this helped to remedy an anomalous situation, as in general philosophy, the concept of rights was always more clearly associated with the individual. ${ }^{101}$ In addition, one might wonder whether the emergence of the principle of self-determination and its gradual strengthening in the context of decolonisation did not also impact on the discussions surrounding the FRS. ${ }^{102}$ With this principle, there was a contender for a collective right more directly associated with the people and thus having an immediate democratic appeal-although the principle need not be associated with democracy in the Western liberal tradition. While the FRS were always seen to have a connection with self-determination in a sense of protecting the independence and political integrity of a state, the 'new' concept of self-determination had the potential to disintegrate states, by shifting attention to those that would have been previously marginalised and deprived of a possibility of realising fundamental

98 On Wengler, see further Andreas Zimmermann, 'International Law Scholarship in Times of Dictatorship and Democracy: Exemplified by the Life and Work of Wilhelm Wengler' in Peter HF Bekker, Rudolf Dolzer and Michael Waibel (eds), Making Transnational Law Work in the Global Economy: Essays in Honour of Detlev Vagts (CUP 2010) 222.

99 Wilhelm Wengler, Völkerrecht, vol II (Springer 1964) 1036. Wengler's analysis is very topical as many works showed considerable confusion about the categories of responsibility and sanctions. See, for instance, the treatise by the former Austrian Chancellor von Schuschnigg in which it was deemed to be a characterising feature of the fundamental rights that breaches would give rise to responsibility, which was and is however the case for all international law: see Kurt von Schuschnigg, International Law: An Introduction to the Law of Peace (Bruce Publishing Company 1959) 109.

100 This connection is hinted at also by international relations scholar Hedley Bull: 'Carried to its logical extreme, the doctrine of human rights and duties under international law is subversive of the whole principle that mankind should be organised as a society of sovereign states.' See Hedley Bull, The Anarchical Society: A Study of Order in World Politics (Macmillan 1977) 152.

101 See also Vec (n 6) 66-67.

102 On self-determination, see Morss (n 6) 93ff; Daniel Thürer and Thomas Burri, 'Self-Determination' in Max Planck Encyclopedia of Public International Law (online edn, 2012) <http://opil.ouplaw.com/view/10.1093/ law:epil/9780199231690/law-9780199231690-e873?rskey=08kTNn\&result=2\&prd=EPIL $>\quad$ accessed 20 November 2015. 
rights in the context of statehood. ${ }^{103}$ While it is difficult to establish causalities here, I find it plausible that the concomitant rise of human rights and self-determination might have had something to do with the relative decline of the doctrine of the FRS.

Be that as it may, German post-war doctrine has come to shy away from using the terminology of the FRS-interestingly so, however, without abandoning the substance of the concept. ${ }^{104}$ Karl Doehring took a somewhat ironic distance from the concept in his treatise. ${ }^{105} \mathrm{He}$ wrote that a listing of the rights and obligations of states under a discrete heading-such as the FRS-could appear to be useless, as the whole of international law would belong to the rules to which states would find themselves bound. In that sense, one could say that states would have to comply with all rules of international law to which they are bound. ${ }^{106}$ Nonetheless, the category of the FRS might fulfil some useful functions. Doehring insisted, however, that the content of these rights should not be developed out of the concept itself, but rather according to the generally recognised methods of the ascertainment of international law, ie through an analysis of state practice, judicial materials and the teachings of international law. ${ }^{107}$

Accordingly, one can see a trend in many German treatises, to rebrand the fundamental rights as fundamental principles of international law. ${ }^{108}$ The reason behind this move is lucidly explained by Volker Epping in a leading German treatise. He argues that the use of the concept of the fundamental rights would be problematic. It would allude to these norms having a higher status, in the way that constitutional law would rank higher than ordinary law. In addition, he makes the important point that thinking in terms of fundamental rights would seem to presuppose a tension between the individual sphere of the rights-holder and a super-imposed legal order. Yet, international law would be characterised by the preeminence of states, them being the lawmakers themselves. Until a genuine supranational order is constructed, it would not be warranted to compare the situation of states with that of individuals in a domestic legal order. ${ }^{109}$

103 As much is hinted at by Scupin (n 6) 724. See also Morss (n 6) 95.

104 An exception is the treatise by Theodor Schweisfurth, Völkerrecht (Mohr Siebeck 2006) 348ff. Similarly, see Torsten Stein and Christian von Buttlar, Völkerrecht (13th edn, Vahlen 2012) 179. An interesting case is Bernhard Kempen and Christian Hillgruber, Völkerrecht (2nd edn, Beck 2007) 165ff (who include the category of fundamental obligations of states but do not speak of fundamental rights); Wolfgang Graf Vitzhum, 'Begriff, Geschichte und Rechtsquellen des Völkerrechts' in Wolfgang Graf Vitzthum and Alexander Proelss (eds), Völkerrecht (6th edn, Walter de Gruyter 2013) 26 (discussing fundamental principles without mentioning the category of fundamental rights).

105 See his highly interesting autobiography: Karl Doehring, Von der Weimarer Republik zur Europäischen Union: Erinnerungen (WJS 2008).

106 Karl Doehring, Völkerrecht (2nd edn, Müller 2004) ss 187-88.

107 ibid s 195. See also Friedrich Berber, Lehrbuch des Völkerrechts. Erster Band: Allgemeines Friedensrecht (C.H. Beck 1960) 179-80, 222.

108 See, eg, Alfred Verdross and Bruno Simma, Universelles Völkerrecht: Theorie und Praxis (3rd edn, Duncker and Humblot 1984) s 451; Christian Tomuschat, 'International Law: Ensuring the Survival of Mankind on the Eve of a New Century' (1999) 281 Recueil des Cours 9, $161 \mathrm{ff}$.

109 Volker Epping, 'Völkerrechtssubjekte' in Knut Ipsen (ed), Völkerrecht (6th edn, Beck 2014) 171. 


\section{An unlikely comeback?}

Accordingly, it might appear as if the category of fundamental rights has finally been put to rest. However, it might be too superficial to leave it at that. It has been noted frequently that the doctrine of the FRS was known under several headings. ${ }^{110}$ They were variably also called fundamental principles, inherent rights, natural rights, etc. They were malleable enough to resurface even after the decline of natural law thinking. Once transformed into a positivist doctrine, they also managed to make it through the more fundamental and foundationalist discussions of the interwar era, only to disappear from the textbook literature after the Second World War. This might incline us to look for modern-day equivalents of this doctrine, or maybe even a re-emergence of the substance of the doctrine which might be cloaked in a different name. Two developments stand out in this regard. In the following, I will argue that modern-day forms of international constitutionalism help to resurrect some form of arguments pertaining to independence and self-preservation of the state which sound familiar if compared to the tradition of the FRS. These arguments no longer aspire to protect 'the state' as such, but rather wish to further democracy. This turn is directed towards the international level. In the absence of credible structures of democratic legitimacy at the international level, these arguments are then redirected to the national level in a form of a Solange argument. ${ }^{111}$ What is more, it can be observed that in the name of democracy and self-determination, the rights to independence and self-preservation have made a comeback through the jurisprudence of the German Constitutional Court on the limits of European and international integration. These two developments are, as will be shown, also discursively connected.

\subsection{Constitutionalism and the calls for democratic legitimacy}

If we return to Epping's critique, it becomes apparent why we may now witness this somewhat unexpected comeback of the dusty fundamental rights concept. Epping's central argument against the possibility of a concept of FRS is the fact that international law would be an order of coordination. ${ }^{112}$ With this remark, he alludes to the horizontality of legal relations in international law and the lack of a central authority. ${ }^{113}$ From this perspective, there is no external authority impacting upon states, which remain free to organise international society as they please. The growing role of international organisations and their law-making powers as well as more generally the emergence of

$110 \mathrm{Vec}(\mathrm{n} 6) 68$.

111 This refers to a type of argument made in BVErfGE 37, 271; 73, 339 (Federal Constitutional Court of Germany).

112 Epping (n 109) 171.

113 Accordingly, his remarks may be concerned primarily with what Friedmann identified as the law of coexistence: see Friedmann (n 32) 89. 
a multitude of different forms of global governance have prompted various scholars to question more generally the democratic legitimacy of international law. ${ }^{114}$

Most prominently, these enquiries have been undertaken by those who follow a constitutionalist agenda. ${ }^{115}$ The transformation of the 'old' inter-state international law into a genuine global order with the individual at its centre is at first sight geared towards making the state redundant and obsolete. ${ }^{116}$ The genuine constitution of international law would reside in international law itself. Whether it is in the Charter of the United Nations $^{117}$ (UN Charter) or a form of compensatory constitutionalism ${ }^{118}$ - where different regimes aspire to fill lacunae in domestic constitutions-most answers to 'the' constitutional question are sought at the international level. However, in what one could call a second wave of constitutionalisation literature, the focus has shifted. Whereas conceptual debates about whether or not international law can have constitutional elements seem to have abated in recent years, there is a growing trend to focus on the alleged democratic deficit of international institutions.

The second wave of literature is related to the first wave in so far as it takes certain elements of the first wave for granted. The debates about the constitutionalisation of international law have made it far more difficult to argue that forms of international cooperation could do with a different form of democratic legitimacy, that such forms of international cooperation may have a legitimatising virtue in themselves. Instead, what happens now is the transposing of domestic concepts of legitimacy to the international level. ${ }^{119}$ Where authority is exercised, so the argument goes, a certain level of democratic legitimacy is called for. ${ }^{120}$

114 See, for instance, José E Alvarez, International Organizations as Lawmakers (OUP 2006) 630; Anne Peters, 'Dual Democracy' in Jan Klabbers, Anne Peters and Geir Ulfstein (eds), The Constitutionalization of International Law (OUP 2009) 263ff; Samantha Besson, 'Sovereignty, International Law and Democracy' (2011) 22 EJIL 373, 376ff; Armin von Bogdandy and Ingo Venzke, In Whose Name? A Public Law Theory of International Adjudication (OUP 2014) $18 \mathrm{ff}$.

115 On the development of the constitutionalist discourse in international law, see Bardo Fassbender, 'Grund und Grenzen der konstitutionellen Idee im Völkerrecht' in Otto Depenheuer, Markus Heintzen and Matthias Jestaedt (eds), Staat im Wort. Festschrift für Josef Isensee (CF Müller 2007) 73; Thomas Kleinlein, 'Between Myths and Norms: Constructivist Constitutionalism and the Potential of Constitutional Principles in International Law' (2012) 81 Nordic J Intl L 79, 81ff. See also for a very useful overview of the existing literature in the field Bardo Fassbender and Angelika Siehr, 'Forschungsbibliographie zum Themenfeld "Konstitutionalisierung jenseits des Staates" in Bardo Fassbender and Angelika Siehr (eds) Suprastaatliche Konstitutionalisierung (Nomos 2012) 313ff.

116 This argument is taken to its extreme in Antônio Augusto Cançado Trindade, International Law for Humankind: Towards a New Jus Gentium (2nd edn, Martinus Nijhoff 2013).

117 Charter of the United Nations (adopted 26 June 1945, entered into force 24 October 1945) 1 UNTS 16 (UN Charter). See generally Bardo Fassbender, The United Nations Charter as the Constitution of the International Community (Martinus Nijhoff 2009).

118 Anne Peters, 'Compensatory Constitutionalism: The Function and Potential of Fundamental International Norms and Structures' (2006) 19 LJIL 579.

119 For a similar diagnosis, see Karen Knop, 'Statehood: Territory, People, Government' in James Crawford and Martti Koskenniemi (eds), The Cambridge Companion to International Law (CUP 2012) 112-13.

120 See, eg, Armin von Bogdandy, Philipp Dann and Matthias Goldmann, 'Völkerrecht als Öffentliches Recht: Konturen eines rechtlichen Rahmens für Global Governance' (2010) 49 Der Staat 23. 
From this argumentative approach, it would not be a long way to transposing domestic standards of legitimacy to the international level. ${ }^{121}$ Yet, as constitutional principles of international law, these principles run into problems of their own: it remains particularly unclear whether they can rely on an international consensus so as to render them customary international law or to make them general principles of law. The limited roots they appear to have in domestic practice rather invites the consideration that we can see here a return of the general principles of 'civilised nations. ${ }^{122}$ At the same time, constitutionalisation theories run into problems of doctrinal construction, which are similar to the ones encountered by the doctrine of the FRS. How can the special, constitutional status of certain rules and principles be established? What follows from this special status? It is of course possible to point towards certain semblances of hierarchy in today's international legal order, such as article 103 of the UN Charter and the concept of jus cogens in the Vienna Convention on the Law of Treaties. ${ }^{123}$ Despite this anchorage of constitutionalist elements in positive international law, the operation of these rules and their exact content and reach remain controversial. ${ }^{124}$

In this light, it is then intriguing to see the category of fundamental rights resurface in newer textbooks as a form of international constitutional law. This move may be seen as both salvaging the doctrine of the FRS from being forgotten and giving the drive towards constitutionalisation a more robust grounding in positive international law. Andreas von Arnauld writes, for instance:

The 'fundamental rights' and 'fundamental obligations' of states comprise, according to a contemporary understanding, the canon of basic legal principles which are indispensable for a peaceful co-existence of states, in some way they are 'constitutional principles of the international community of states. ${ }^{\text {.25 }}$

\subsection{Democracy as a shield: A view from practice}

Nowhere has the impact of international law on states and their domestic law become more palpable than in the context of European integration. ${ }^{126}$ It is a matter of longstanding

121 A significant engagement with the legitimacy concerns can be found in Mattias Kumm, 'The Legitimacy of International Law: A Constitutionalist Framework of Analysis' (2004) 15 EJIL 907.

122 cf Martti Koskenniemi, 'The Politics of International Law: 20 Years Later' (2009) 20 EJIL 7, 17.

123 VCLT, arts 53, 64.

124 On tendencies towards hierarchy in international law, see Thomas Kleinlein, Konstitutionalisierung im Völkerrecht: Konstruktion und Elemente einer idealistischen Völkerrechtslehre (Springer 2012) 315ff. For canonical criticism, see Prosper Weil, 'Towards Relative Normativity in International Law' (1983) 77 AJIL 413. Specifically on art 103 of the UN Charter, see Andreas Paulus and Johann Ruben Leiß, 'Article 103' in Bruno Simma and others (eds), The Charter of the United Nations: A Commentary, vol II (3rd edn, OUP 2012) 2110ff.

125 Andreas von Arnauld, Völkerrecht (2nd edn, Müller 2012) 126-27. For a related argument from the interwar era, see Friedrich August von der Heydte, 'Die Erscheinungsformen des zwischenstaatlichen Rechts; jus cogens und jus dispositivum im Völkerrecht' (1932) 16 Zeitschrift für Völkerrecht 461, 465-66.

126 See further Andreas L Paulus, 'Germany' in David Sloss (ed), The Role of Domestic Courts in Treaty Enforcement: A Comparative Study (CUP 2009) 209ff. 
debate to what extent the European Union (EU) has shaken off its public international law origins. ${ }^{127}$ While the EU is in very many senses a special animal, ${ }^{128}$ it is not so different from other international organisations that the dynamics between EU law and the domestic legal orders of its member states would be of no interest to the international lawyer. It is in this context that the German Federal Constitutional Court has developed its jurisprudence on the limits of European integration. The relationship of the Court with the broader project of European integration in general, but also with its counterpart in Luxembourg, has been described many times and need not be recounted here in great detail. $^{129}$

What is of interest here, is a certain style of arguing, which has developed in the more recent decisions of the Karlsruhe Court on questions of European integration, starting with the judgment on the German legislation implementing the Lisbon Treaty in 2009 (Lisbon Treaty case). ${ }^{130}$ As I will argue in this section, this jurisprudence shows certain resemblances to the doctrine of the FRS. At the same time, it can be seen as a correlation to the second wave of constitutionalisation literature. This is not to say that the Constitutional Court was inspired by this literature or that, the other way around, this stream of literature would enthusiastically embrace the findings of the Lisbon Treaty case. Yet, if seen together, the recent literature on democratic legitimacy in international law and the jurisprudence of the German Federal Constitutional Court can be seen as two sides of the same coin. Both erect barriers to international and European integration in the name of democracy.

The Lisbon Treaty case arose out of a number of individual constitutional complaint procedures as well as disputes between constitutional organs. They all revolved around the question of whether German sovereignty and the rights of the German parliament and its members would be infringed by the Lisbon Treaty which amended the constitutional foundations of the EU. The practical outcome of the case appears to be rather uneventful: the complaints and disputes did not prevent German ratification of the Lisbon Treaty. Instead, the Court held that there was a requirement to pass additional German legislation for accompanying the process of European integration; legislation which was arguably needed in order to make German participation in the EU more democratic and transparent. The real significance of the decision lies, however, in the numerous obiter dicta of the Court in which its broader

127 For an excellent treatment of this question, see Bruno de Witte, 'The European Union as an International Legal Experiment' in Gráinne de Búrca and Joseph HH Weiler (eds), The Worlds of European Constitutionalism (CUP 2012) 19.

128 See further Georg Nolte and Helmut Philipp Aust, 'European Exceptionalism?' (2013) 2 Global Const 407.

129 On the most recent developments, ie the reference for a preliminary ruling on certain policies of the European Central Bank together with a contextual analysis of the case law of the Court, see Mattias Wendel, 'Exceeding Judicial Competence in the Name of Democracy: The German Constitutional Court's OMT Reference' (2014) 10 Eu Const 263.

130 Lisbon Treaty decision of Germany's Federal Constitutional Court Judgment, 2 BvE 2/08 (2009) paras 126, 267 (Lisbon Treaty case). An English translation of this judgment is available at <http://www.bverfg.de/ entscheidungen/es20090630_2bve000208en.html> accessed 17 November 2015. All subsequent references refer to this English translation. 
philosophy of the project of European integration is spelled out in great detail. This philosophy hinges on democratic self-determination and a necessity to preserve a space for democratic deliberation within the German polity. ${ }^{131}$ It is in this regard that a connection to the doctrine of the FRS can be drawn. In procedural terms, the cases all hinged on the interpretation of the right to vote and the corresponding legal positions of members of parliament under article 38(1) of the Basic Law of Germany. This guarantee can be invoked by individuals in constitutional complaint procedures under article 93 of the Basic Law and is thus the procedural gateway through which action against new treaty commitments of the Federal Republic can be channelled, presupposing an argument that such new commitments would erode the competences of the German Bundestag. ${ }^{132}$ With respect to the right to vote in article 38(1) of the Basic Law, the Federal Constitutional Court held that it establishes a right to democratic self-determination. ${ }^{133}$ This idea would pervade the whole constitutional order as 'citizens are not subject to an inescapable political power, which they are fundamentally incapable of freely determining. ${ }^{134}$ Further, 'Self-determination of the people according to the majority principle, achieved through elections and other votes, is constitutive of the state order as constituted by the Basic Law. ${ }^{135}$ This ideal of democracy and self-determination would not be open for a balancing exercise with other constitutional values. It would be inviolable and would therefore benefit from the protection of the so-called 'eternity clause' in article 79(3) of the Basic Law, which protects the principles laid down in articles 1 and 20 of the Basic Law even against constitutional amendment. ${ }^{136}$

So far, it could be said that this reasoning applies on the level of domestic law only. With Germany generally following a dualist model for the organisation of the relationship between international and domestic law, ${ }^{137}$ these dicta would seem to have no relationship to the concept of the FRS, or for that matter the people-as a collectiveon the international level. However, this reasoning is too simplistic. ${ }^{138}$ It has become

131 This decision has given rise to a vast array of literature. For further analysis of this decision, see, among others, Daniel Halberstam and Christoph Möllers, 'The German Constitutional Court Says "Ja zu Deutschland!'” (2009) 10 German LJ 1241; Christoph Schönberger, 'Lisbon in Karlsruhe: Maastricht's Epigones at Sea' (2009) 10 German LJ 1201; Daniel Thym, 'In the Name of Sovereign Statehood: A Critical Introduction to the Lisbon Judgment of the German Constitutional Court' (2009) 46 CMLR 1795; Matthias Ruffert, 'An den Grenzen des Integrationsverfassungsrechts: Das Urteil des Bundesverfassungsgerichts zum Vertrag von Lissabon' (2009) DVBL 1197.

132 For a critical assessment of this doctrine, see M Nettesheim, 'Ein Individualrecht auf Staatlichkeit? Die Lissabon-Entscheidung des BVerfG' (2009) NJW 2867.

133 Lisbon Treaty case (n 130) para 208.

134 ibid para 212.

135 ibid para 213.

136 ibid para 216.

137 ibid paras $111,307,318$.

138 It can be debated how useful the monism/dualism debate still is: see Armin von Bogdandy, 'Pluralism, Direct Effect and the Ultimate Say: On the Relationship between Domestic and International Constitutional Law' (2008) 6 IJCL 397. 
almost a trend among domestic-and for that matter EU-courts in recent years, to engage in quasi-review of international law, only to limit the reach of their findings by pointing to them being contained to the domestic level. ${ }^{139}$ We have seen this both in the US Supreme Court's Medellin case ${ }^{140}$ as well as in the decision of the Court of Justice of the European Union in Kadi $I^{141}$ Also the recent snub of the Italian Constitutional Court towards the International Court of Justice decision in the Jurisdictional Immunities case rests on this line of argument. ${ }^{142}$ The Lisbon Treaty case follows a similar path of reasoning, being on its face only concerned with the domestic implementation of an international agreement changing the constitutional foundations of the EU. However, the Federal Constitutional Court itself noted the intimate relationship between the German Basic Law and broader international developments of constitutionalism:

Through what is known as the eternity guarantee, the Basic Law reacts on the one hand to the historical experience of a creeping or abrupt erosion of the free substance of a democratic fundamental order. However, it makes clear on the other hand that the Constitution of the Germans, in accordance with the international development which has taken place in particular since the existence of the United Nations, has a universal foundation which cannot be amended by positive law. ${ }^{143}$

This is, of course, also the bridge which allowed the Court to bring in the principle of the so-called 'Völkerrechtsfreundlichkeit', embodying the general openness of the German constitutional order towards international law. Sovereignty and selfdetermination would not be ends in themselves. ${ }^{144}$ Yet, however wide-ranging the powers to participate in processes of European and international integration would seem to be, they are not limitless. EU member states would need to retain their constitutional identity and must not 'lose their ability to politically and socially shape living conditions on their own responsibility.' ${ }^{145}$ The Basic Law would not grant 'powers to bodies acting on behalf of Germany to abandon the right to self-determination of the German people in the form of Germany's sovereignty under international law by joining a federal state. ${ }^{146}$ Again, the Court's arguments stray along the boundaries

139 For a very insightful comparative analysis, see Gráinne de Búrca, 'The European Court of Justice and the International Legal Order after Kadi' (2010) 51 Harvard Intl LJ 1.

140 Medellin $v$ Texas 522 US 491 (2008).

141 Cases C-402/05 P and C-415/05 P Kadi and Al Barakaat International Foundation $v$ Council and Commission [2008] ECR-I 6351.

142 Sentenza no 238/2014 della Corte Constituzionale, 22 October 2014. An English translation of this judgment is available at <http://www.cortecostituzionale.it/documenti/download/doc/recent_judgments/S238_2013_ en.pdf > accessed 17 November 2015. See on this case Stefan Raffeiner, 'Italien im Dilemma zwischen Verfassungs- und Völkerrechtstreue' (Verfassungsblog, 25 October 2014) <http://www.verfassungsblog. de/italien-im-dilemma-zwischen-verfassungs-und-voelkerrechtstreue-2/\#.VHaph8mPcvs $>$ accessed 27 November 2014. The decision of the International Court of Justice in question is Jurisdictional Immunities of the State (Germany/Italy, Greece intervening) (Merits) [2012] ICJ Rep 99.

143 Lisbon Treaty case (n 130) para 128.

144 ibid para 220.

145 ibid para 226.

146 ibid para 228. 
of domestic constitutional and international law. The Court remarked that an EU constitutional order would remain a derivative one whereas '[i]n contrast, sovereignty under international law and public law requires independence from an external will precisely for its constitutional foundations. ${ }^{147}$ It would not be tolerable that no 'sufficient space is left to the Member States for the political formation of the economic, cultural and social living conditions. ${ }^{148}$

Taken together, the Court has developed out of sparse constitutional wording an elaborate set of limits for international and European integration. These limits resemble in some ways the FRS, in particular the right to political independence. What the Court is arguing for is essentially a right to keep a free hand over association with other states in the EU. This might require reconsidering previous treaty commitments at least in the sense that German state organs would not be mandated to go along with certain developments of EU power-echoing Kaufmann's insistence on the clausula rebus sic stantibus as the ultimate rule against which to measure state behaviour.

\section{Conclusion: Fundamental rights of states in times of upheaval and systemic change}

The case law of the Federal Constitutional Court is, of course, not a straightforward embrace of the doctrine of the FRS. However, it has been noted several times that this doctrine has always had an existence under varying names and with different functions. Accordingly, in analysing its current relevance it would be too short-sighted to look only for instances in which it is called by its original name. Somewhat unwittingly, the constitutionalist literature of the last ten to twenty years has helped to reintroduce argumentative patterns not wholly unrelated to the doctrine of the FRS. Yet it needs to be asked openly for whom these fundamental rights exist. A similar debate has developed over the equally contested notion of the international rule of law. Jeremy Waldron in particular has asked whether states should benefit from the rule of law in the way that individuals are protected by it at the domestic level. ${ }^{149}$ To a certain extent, this is a parallel discussion to the one concerning the FRS. Waldron was sceptical and reaffirmed what Georges Scelle, Hans Kelsen and others had already found earlier: that states were only trustees for individuals, fulfilling public functions. ${ }^{150}$ From this, he extrapolated that states are not in need of protection through the international rule of law. ${ }^{151}$ Whereas this may ignore that power relationships among states may very well call

147 ibid para 231.

148 ibid para 249.

149 Jeremy Waldron, 'Are Sovereigns Entitled to the Benefit of the International Rule of Law?' (2011) 22 EJIL 315.

150 For a related and recent argument, see Eyal Benvenisti, 'Sovereigns as Trustees of Humanity: On the Accountability of States to Foreign Stakeholders' (2013) 107 AJIL 295.

151 Waldron (n 149) 327, 341ff. 
for some form of rule of law requirements at the interstate level, ${ }^{152}$ his note of caution can also be transferred to the discussion on the ongoing value of the category of the FRS.

As it is so often the case, the history of international law does not lend itself to fast and easy conclusions about causalities. Yet, it appears to the present author that the doctrine of the FRS has enjoyed its heyday of popularity in times of upheaval and change. When the foundations of the international legal order-or the role of the state in which international lawyers worked-were shifting and unclear, recourse to the doctrine of the FRS intensified. It would be problematic to propose clear-cut motivations for these moves and to pretend that the development of a complex and varied academic discourse can be reduced to an epiphenomenon of geopolitical change and soul searching about the position of a given state in the international community. Yet, international lawyers are also products of their time and work in specific political and social conditions. Accordingly, it can be asked whether the popularity of the doctrine of the FRS in late nineteenth- and early twentieth-century German academia had something to do with a wish to fortify Germany's ambitions as a latecomer in the concert of European powers. The currency of the doctrine of the FRS after the First World War seems to be related to the widely perceived injustice of the Versailles peace treaty, later blending into early attempts to define a National Socialist international law. The return of the doctrine under the guise of the natural law renaissance after the Second World War goes to show, if anything, the malleability of the doctrine, which was then resorted to in order to find a language for thinking about a new international legal order after the Second World War. In more recent times, it appears as if the insecurities associated with the growing impact of international and EU law on the German constitutional system have paved the way for its unlikely comeback.

The development of international law is in constant flux. Phases of optimism, such as in the aftermath of the Cold War, blend into despair such as in 2003 over the USled invasion of Iraq. ${ }^{153}$ Again some ten years later, the prospects of international law may appear to be bleak, with the situations in Syria and Ukraine as well as the rise of 'Islamic State' seriously questioning the ability of international law to cope with current crises. Yet, at the same time another kind of international law seems to blossom. It is the international law of the bureaucrat, the functionalist machinery of international organisations $^{154}$ and, perhaps even more troubling, the informal groupings of states exercising their sweeping powers over weaker states and individuals alike. ${ }^{155}$ It is in this

152 For an argument in favour of an interstate conception of the rule of law, see Helmut Philipp Aust, Complicity and the Law of State Responsibility (CUP 2011) 53ff.

153 Georg Nolte, 'Persisting and Developing Between Hope and Threat: International Law During the Past Two Decades and Beyond' in James Crawford and Sarah Nouwen (eds), Select Proceedings of the European Society of International Law, vol 3 (Hart Publishing 2010) 75-78.

154 See Jan Klabbers, 'The Emergence of Functionalism in International Institutional Law: Colonial Inspirations' (2014) 25 EJIL 645.

155 For a recent attempt to make sense of this development, see Joost Pauwelyn, Ramses A Wessel and Jan Wouters, 'When Structures Become Shackles: Stagnation and Dynamics in International Lawmaking' (2014) 25 EJIL 733. 
setting that calls for the democratic legitimacy of international law gain currency. The reaction of the German Federal Constitutional Court also seems to fit into this picture. Here, a return to the category of FRS seems to enjoy an intuitive plausibility, helping to nourish democracy against faceless machineries of bureaucracy and managerialism. Yet, recourse to the ideology behind the fundamental rights of states can, arguably, not be limited to these fields. Rather, it is likely to pervade the whole of international law and risks undermining its often challenged normativity. If this new emanation of the doctrine of the FRS is not to be regarded as a Sonderrecht (special law) for Western and liberal democracies, it would also need to be attuned to the sensibilities of other states, which might utilise this doctrine for purposes which would probably decouple the doctrine again from notions of democratic self-government. If that is in the interest of those now putting a premium on the democratic legitimacy of international law is an open question. 